\title{
The Right of Religious Institution to Acquire Legal Personality in Ethiopia: Emphasis on the New Proclamation to Provide Legal Personality to Ethiopian Islamic Affairs General Council
}

\author{
Enyew Deresse Arkew (Lecturer) \\ School of Law, Arba Minch University, Ethiopia
}

\begin{abstract}
Besides, the separation of the teachings of each religion and the way religions organize their followers complicates matters, historical contexts make it different for how religions are recognized and legitimate. Countries accept the principles of freedom of religion and state separation of religion, but the application of these principles varies from country to country. The Ethiopian Orthodox Church has a legal body per Article 398 of the Ethiopian Civil Code, while other faith organizations have access to the statutory body at the registration of the relevant government. Therefore, this paper comparatively examines a legal framework which is prepared by the Ministry of Peace to address these gaps and related questions of the Muslim community, and how Ethiopia recognizes and governs religious institutions that are closely linked to their history. Thus, it concludes that, with the long history of Islam in Ethiopia, and the number of adherents of the religion, it would be appropriate to proclaim by the legislature rather than on the registration of ordinary institution.
\end{abstract}

Keywords: Religious institution, registration, legal personality, Islam, Proclamation, Ethiopian Legal framework. DOI: $10.7176 / \mathrm{DCS} / 10-10-03$

Publication date:October $31^{\text {st }} 2020$

\section{Introduction}

Christianity entered in Ethiopia during the Axumite Empire in the $4^{\text {th }}$ century, so Ethiopia is one of the oldest countries in Africa to welcome Orthodox Christianity. ${ }^{1}$ Islam also had an old history in Ethiopia, in the 615 the first Muslims who escape persecution in Mecca Came to Ethiopia. In the $16^{\text {th }}$ Century, the Roman Catholic Church also entered Ethiopia as a result of the relationship between Ethiopia and the Portuguese. ${ }^{2}$

The Orthodox Church has dominated the political, social, and cultural life, especially in the northern highlands, and it has been the official religion in the Christian highlands kingdom and until Emperor Haile Selassie was over through by the military Government in 1974. The Church played a pivotal role both in the state and nation-building process in Ethiopia.

Accordingly, in July 2018, the US government estimated the total population of Ethiopia is 108.4 million. $^{3}$ Therefore, based on this census, $44 \%$ of the population estimated follows to Ethiopian Orthodox Church, 34\% are Sunni Muslim, 19\% of the population the followers of Christian Evangelical and Pentecostal, and less than 5\% group of the population are Roman Catholics, Jehovah's Witness, Jews, and indigenous religion practitioners. ${ }^{4}$

The Ethiopian Orthodox Church predominates mostly in the northern regions of Amhara and Tigray, although Islam prevalent in the Afar, somehow in Oromia (not all parts), and Somalia regions. Protestant Churches mostly in Southern, Nation, nationalities and people's regions, and some parts of Oromia regional state

\section{Status and Recognition of Religious institutions under the Ethiopian Constitution}

In Ethiopia, the 1995 Constitution of Ethiopia introduced the first secular state by law. The new Constitution Promulgated in a clear and precise manner freedom of religion as well as the separation of state and religion. ${ }^{5}$

The Ethiopian constitution stipulated the separation of state and religion, established freedom of religious choice, prohibits religious discrimination, and the government shall not interfere in matters of any religion, nor shall religion interfere in government affairs. ${ }^{6}$ But the religious practice is not absolute and is not escape from limitation, so the law limits religious freedom to protect public safety, education, and public morals. ${ }^{7}$ It is a criminal act to defamed and incite one religious' group to another.

In addition to this, the Ethiopian Constitution permits Sharia courts to adjudicate Civil and Personal status cases, it needs both parties to be Muslim and both parties in dispute should give their consent to the court's jurisdiction. Article 34(5) of the FDRE Constitution which reads: "This constitution shall not preclude the adjudication of disputes relating to personal and family laws under religious or customary laws with the consent

\footnotetext{
${ }^{1}$ Gordon Melton and Martin Baumann (editors), Religions of the world, 2010, p.1004.

${ }^{2}$ See http://www1.uni-hamburg.de/ethiostudies/PERSONAL/martinezaethiopica2006, Last accessed, June 16, 2020

${ }^{3}$ International Religious Freedom Report for 2018 United States Department of State Bureau of Democracy, Human Rights, and Labor

${ }^{4}$ Supra note 4

${ }^{5}$ The 1995 Ethiopian Constitution Article 27

${ }^{6}$ Article 27 of the Ethiopian Constitution

${ }^{7}$ Article 27/5 of the Ethiopian Constitution
} 
of the parties to the dispute."1

However, the law on the registration of religious organizations was seen to contradictory to the provisions of religious freedom and equality stipulated under the Constitution. Yet, the Ethiopian Orthodox Church is exempt from registration by the civil code of 1960. And also the Ethiopian Orthodox Church established by the 1960 civil code under Article 398, whereas for all others registration was a legal mandate to register like any ordinary association.

Outside of the Orthodox Church, all religions must register like association and renew every five years, failing to renewal constitutes fine punishment. You can imagine the renewal regime serving as a basis for discrimination.

On the one hand, the Directorate of Faith and Religious Affairs of the Ministry of Peace mandated registration and licensing of religious groups. The registration process requires the applicant's religious group must have at least 50 individuals for registration as a religious entity. ${ }^{2}$

The registered religious group must submit reports which describe evangelical activities and 'list new members, and if there are new houses of worship. ${ }^{3}$ Within this process, Protestants complained about the discrimination act of local officials against them concerning religious registration and allocation of land for churches. ${ }^{4}$ All the same, the religious right to legal personality concerning the establishment was a long-standing question of the Muslim community in the Ethiopian legal regime.

\section{The New Proclamation to Provide Legal Personality to Ethiopian Islamic Affairs General Council (June, 2020), and Freedom of faith: A Comparative Analysis}

\subsection{General Overview}

Freedom of faith is a fundamental human right recognized by the Ethiopian Constitution, and which are recognized by various human right and international treaties. Part of this right, as provided in Article 27/2 of the Ethiopian Constitution, is to establish religious institutions that enable religious people to promote and organize their religion. Religious institutions are very important for the activities of the members of a religion in their freedom of belief and worship. These institutions should have the legal body to provide good service to religious people. Like any other body of law, religious institutions have the associated rights to own, lease, enter into contracts, sue, and be sued.

Religious institutions are a mere set of individuals without a legal body, and they are subject to various problems in their interactions with government, other institutions, and individuals if they lack legal personality. They do not have the legal capacity to invest in property, manage resources, and be fully recognized in court and other government structures.

Ethiopia is the foremost country in the history of the Islamic religion as the foremost refuge for Muslims in any Muslim country. However, registering as an ordinary society without a strong legal foundation has been demanding for centuries, the Muslim community has caused many problems.

It would be proper for the Muslim community to legally recognize the size of the population in the country, its role in the size of the country, and the religious administration that does not need to be regularly registered and renewed per the federal structure. As a result, the Muslim has raised questions on various occasions to have legal personality through the establishment proclamation like the Ethiopian Orthodox Church, therefore, this proclamation enacted in the response of those questions of the Muslim community.

\subsection{Countries Experiences in Establishing Religious Institutions}

Countries provide legal bodies or religious bodies to religious institutions to respect religious freedom, especially in respect of the right to establish religious institutions and institutions of their religion. In the Secular States, where the principle of religion and government is respected, the legal body is given to religious institutions by submitting the necessary criteria to the registration of religious institutions per laws governing the establishment and registration of religious institutions.

While this is a common approach, there are also countries where different options are implemented. One of these alternatives is the agreement between the religious institution and the government. Another way to provide legal bodies to religious institutions other than registration is by establishing that the legal body of the institution is directly derived from the law or by the legislature.

According to the Ethiopian civil code of Article 398 sub 1, the Ethiopian Orthodox Church is considered to be one person by law. This means that the Church is a body of law and can be legally obligated. Article 398/1 proclaimed: "The Ethiopian Orthodox Church is regarded by law as a person, and as such, it can have and exercise, through its organs, all the right which are vested in it by the administrative laws."

\footnotetext{
${ }^{1}$ Article $34 / 5$ of the Ethiopian Constitution

${ }^{2}$ International Religious Freedom Report for 2018 United States Department of State Bureau of Democracy, Human Rights, and Labor

${ }^{3}$ Ibid

${ }^{4}$ Ibid. p.5

${ }^{5}$ The 1960 Ethiopian Civil Code Article 398/1
} 
As an example of Austrian experience, it can be cited as giving legal recognition to religious institutions. Austria recognizes the Protestant and Islamic faith institutions. Greece, in its 2014 decree, directly awarded eight religious' bodies. When such options are followed by countries, it is to recognize the role of the religious body directly in the legal proclamation, considering their role in the country's history, culture, and tradition. This kind of recognition is associated with the number and history of religious people in the country.

In Ethiopia, the problem is creating a different legal regime in registration or acquiring legal personality but it's not denying accessing such status. On the other hand, there are so many countries that restricted the right of religious communities to acquire legal personality.

For instance, in 2012, Kazakhstan restricted several religious institutions from registration, this restriction and religious ban amended in December 2016, and 2017. The amendment of religious restriction and ban law increased the punishments, and 'state control of religious,' and 'foreign religious travel.'

In Kenya also the registration authority didn't register any new religious institutions; more than 4,400 religious group applications were pending in authority. ${ }^{2}$ Although the registrar of societies prohibited Atheists from registration, latter the High Court in Nairobi reversed the decision to suspend the registration of the Atheists.

In Bulgaria, the case between Genov v. Bulgaria, ${ }^{3}$ The applicant, Asen Genov, is a Bulgarian national, who was born in 1969 and lives in Sofia. ${ }^{4}$ The case concerned the authorities' refusal to register the new religious association. Mr. Genov asserted that the refusal to register had entailed a violation of his rights under Articles 9 (freedom of thought, conscience, and religion) and 11 (freedom of assembly and association) of the European Convention on Human Rights. ${ }^{5}$ The European Court of Human Rights held that Bulgaria violated the ECHR by failing to recognize this new religious group. ${ }^{6}$

\subsection{The new Ethiopian Islamic Affairs General Council Proclamation 2020}

The title of the Proclamation is a proclamation to provide the legal body of the General Council of Islamic Affairs of Ethiopia. According to Article 2, titled giving legal bodies, the Ethiopian Council of Islamic Affairs and its entities and associations have been granted legal recognition under this proclamation without the need for separate registration. ${ }^{7}$ This provision is the main cause of the proclamation and the execution of the proclamation. Therefore, the Islamic General Council is legally recognized, and organizations and associations that are established will have a legal personality.

Article 4 provides for the budget of the House and, accordingly, the budget of the House shall be covered by funds from within and outside the country, by timely contributions from the Muslim community, by religiously approved fees and benefits. Notwithstanding the above, the Council is also engaged in income-generating activities. ${ }^{8}$

The Council is expected to have a clear financial and financial management system. The purpose of this provision is to clarify the source of funding so that there is no question of budgetary allocation. Because of the need for clarity in language, the council's working language is regulated by the statute based on federal and regional working languages. ${ }^{9}$

The provisions of the passage of Article 6/2/ shall be stipulated that the establishment of this Council shall not deprive the nation of Muslim's right to organize and register their religious institutions at different regional and federal levels. ${ }^{10}$

The purpose of this Act is to ensure that religious groups are free to establish, organize, and operate their institutions at the expense of the Council. Article 6/2 / of the Proclamation is included in the Proclamation to protect the right to the constitutional freedom of belief so that there is no presumption that the creation or organization of other Muslim institutions is prohibited.

\section{Conclusion}

After the 2018 reform and the coming of Prime Minister Abiy Ahmed things are going to change, Abiy Ahmed, who is from both a Christian and Muslim background, tried to reform the Ethiopian politics from Revolutionary Democracy to Liberal, the revision of the Charities and Civil Society proclamation, electoral laws, revision of Anti-terrorism proclamation, the enactment of new Administrative procedure laws and so on... within this reformation, one crucial change concerning religious freedom of faith and worship is, the enactment of $\mathrm{A}$

\footnotetext{
${ }^{1}$ W. Cole Durham, Jr. and Brett G. Scharffs, Law and Religion: National, International, and Comparative Perspective. Second Edition 2019

${ }^{2}$ Freedom in the world 2015: the annual survey of political and civil liberties. By freedom house.

${ }^{3}$ W. Cole Durham, Jr. and Brett G. Scharffs, supra note 13

${ }^{4}$ Genov v. Bulgaria, May 2017

${ }^{5}$ Ibid

${ }^{6}$ Ibid

${ }^{7}$ Article 2 of the proclamation to provide Legal personality to Ethiopian Islamic Affairs General Council, 2020

${ }^{8}$ Article 4 of the proclamation to provide Legal personality to Ethiopian Islamic Affairs General Council, 2020

${ }^{9}$ Article 5 of the proclamation to provide Legal personality to Ethiopian Islamic Affairs General Council, 2020

${ }^{10}$ Article 5 of the proclamation to provide Legal personality to Ethiopian Islamic Affairs General Council, 2020
} 
proclamation to provide Legal personality to the Ethiopian Islamic Affairs General Council and the Evangelical church proclamation is the most prominent law which able to response the religious long-lasting questions.

Enacting religious establishment proclamation by a statutory body is not a violation of the principle of separation of religion as it is a government that gives legal personhood by registration and proclamation. Moreover, since the passage of the proclamation does not merely endorse or elevate the Islamic religion or its leadership, it does not deem the government's interference in one religion, nor does it justify injustice on other religious institutions. The legal body of the General Council of Islamic Affairs in Ethiopia does not violate the special privileges and privileges of other faiths, especially concerning taxation and government subsidies, and does not infringe on equal rights of citizens. Rather, this Proclamation provided the legal personality of the Supreme Council of the Ethiopian Islamic Affairs General Council which allows de jure equal status for Ethiopian Muslims. And other institutions of faith can obtain this kind of recognition directly by the establishment of proclamation.

\section{References}

Case, Genov v. Bulgaria, May 2017

Freedom in the world 2015: the annual survey of political and civil liberties. By freedom house

Gordon Melton and Martin Baumann (editors), Religions of the world, 2010

International Religious Freedom Report for 2018 United States Department of State Bureau of Democracy, Human Rights, and Labour

The 1995 Ethiopian Constitution

The 1960 Ethiopian Civil Code Article 398/1

The proclamation to provide Legal personality to Ethiopian Islamic Affairs General Council, 2020

W. Cole Durham, Jr. and Brett G. Scharffs, Law and Religion: National, International, and Comparative Perspective. Second Edition 2019

http://www1.uni-hamburg.de/ethiostudies/PERSONAL/martinezaethiopica2006, Last accessed, June 16, 2020 